\title{
WUJUD EKSPRESI DALAM PEMANFAATAN RUANG SITUS GUA KARAS KAIMANA \\ (A Form Expression in The utilization of The Karas Kaimana Cave's Space)
}

\author{
Zubair Mas'ud \\ Balai Arkeologi Jayapura \\ bairpapua@yahoo.co.id
}

\begin{abstract}
This essay will explain about the form of the utilization of the cave karas that has lasted in the past. The path of activity seen with the finding in the form of an artifact and ecofak that is concerned the environment and the presence of an image on walls and ceilings caveman. In this research using a qualitative approach with a descriptive method. The technique of collecting data through study of literature, observation, and excavation. Next the data has got processed until the conclusions and advice found. The findings results excavation and observation in the karas cave then noted and done a summation after classified.Based on the results of this research, the analysis showed that the cave had been utilized as a Karas cave $d$ welling. These findings indicate the utilization of cave dwelling on aspects as Karas horizontal as well as vertical side burial. In addition, the existence of human bone fragments and the findings of the existence of the pictures on the cave's wall shows a connection with the utilization of space in the karas cave. Thus the existence of archaeological findings related to the cultural process in utilizing space in Karas cave.
\end{abstract}

Keywords: expression, the utilization, space, Karas cave

\begin{abstract}
ABSTRAK
Tulisan ini mengungkapkan tentang bentuk pemanfaatan gua Karas yang telah berlangsung pada masa lalu. Jejak aktifitas terlihat dengan adanya temuan berupa artefak dan ekofak yang berkaitan lingkungan maupun adanya gambar pada dinding dan langit-langit gua. Pada penelitian ini menggunakan pendekatan kualitatif dengan metode deskriptif. Teknik pengumpulan data melalui studi pustaka, observasi, dan ekskavasi. Selanjutnya data yang diperoleh diolah sampai pada penyusunan interpretasi hingga pada kesimpulan dan saran. Temuan hasil ekskavasi dan observasi di gua Karas kemudian dicatat dan dilakukan penjumlahan setelah diklasifikasikan. Berdasarkan hasil analisis dari penelitian ini, memperlihatkan bahwa gua Karas pernah dimanfaatkan sebagai gua hunian. Temuan tersebut menunjukkan pemanfaatan gua Karas sebagai hunian pada aspek horizontal sekaligus sebagai penguburan pada sisi vertikal. Selain itu, adanya temuan fragmen tulang manusia dan keberadaan gambar pada dinding gua menunjukkan adanya hubungan dengan pemanfaatan ruang di gua Karas. Dengan demikian keberadaan temuan arkeologis berkaitan dengan proses budaya dalam memanfaatkan ruang di gua Karas.
\end{abstract}

Kata kunci: ekspresi, pemanfaatan, ruang, Gua Karas

Tanggal masuk : 1 September 2014

Tanggal diterima : 3 November 2014 


\section{PENDAHULUAN}

Pada tahun 2010, sebuah tim penelitian melakukan eksplorasi di wilayah Teluk Arguni, Kabupaten Kaimana, Provinsi Papua Barat. Tim ini menamakan diri sebagai Tim Ekspedisi Intersains Lengguru-Kaimana. Untuk pertama kalinya berhasil menemukan dan melakukan penelitian di gua Karas yang berpotensi sebagai hunian pada masa lalu. Tim Ekspedisi Intersains Lengguru-Kaimana dalam penelitiannya di gua Karas melakukan survei permukaan gua dan membuka tiga lubang uji (test pit). Penggalian dari 3 (tiga) lubang uji (test pit) di gua ini menghasilkan data berkaitan dengan jejak hunian prasejarah tertua di wilayah kabupaten Kaimana.

Kesimpulan tersebut berdasarkan temuan arkeologi yang diperoleh berupa fragmen tembikar, cangkang kerang, alat cangkang kerang, tulang hewan, alat tulang dan alat batu dan kubur manusia. Khusus untuk kubur manusia, temuan tersebut berupa satu rangka utuh yang merupakan kuburan primer. Bagian rangka yang ditemukan berupa bagian badan yang terdiri dari tulang rusuk (coste) dan tulang belakang (vertebrae). Sedangkan bagian lain seperti kepala, tangan dan kaki terdapat di bagian lain yang tidak sempat digali. Pada bagian bawah terdapat batu-batu gamping kecil yang kemungkinan disusun sebagai alas bagi si mati. Pada bagian atas rangka terdapat temuan fragmen tepian tembikar hias (http://lengguru.org).

Berdasarkan hasil survei permukaan dan pembukaan lubang uji (test pit) dalam ekspedisi tersebut menunjukkan bahwa gua Karas memiliki potensi arkeologis yang tinggi. Karakter budaya kehidupan di gua berupa sisa makanan baik fauna darat maupun air, fragmen gerabah dan rangka manusia ditemukan di gua ini. Selain itu, terdapat pula gambar lukisan gua pada tebing dan langitlangit gua dengan penggunaan warna hitam.

Data pengamatan lukisan yang terdapat di gua Karas dapat diklasifikasikan mengacu pada klasifikasi dan terminologi rock arts menurut L. Maynard (1977), secara teknis terdiri atas lukisan figuratif dan non figuratif. Contoh untuk bentuk figuratif meliputi gambar orang, binatang ataupun tapak tangan, sementara non figuratif meliputi gambar yang berupa garis dan bentuk oval (Wiradyana, 2011).

Kesadaran manusia akan adanya kekuatan tertentu yang terdapat di alam sekitarnya dan juga dalam tubuh manusia, menjadikan manusia memiliki perilaku khusus terhadap alam dan orangyangmeninggal. Perilakutersebut merupakan cerminan dari religi yang berlangsung pada waktu itu khususnya perlakuan manusia terhadap si mati. Kekuatan tertentu yang ada pada tubuh manusia yang kemudian disebut roh dipercayai hidup kembali di alam arwah jika roh tersebut meninggalkan badan manusia. Mengingat adanya kekuatan di atas kekuatan manusia di alam sekitar dan roh pada tubuh manusia, maka masyarakat prasejarah memberlakukan si mati dengan perlakuan khusus (Subroto, 1986).

Meski telah dilakukan penelitian oleh Tim Ekspedisi Intersains Lengguru-Kaimana, namun ada hal yang belum terjawab dan guna mendukung interpretasi yang luas. Untuk itu dilakukan penelitian lanjutan dengan ekskavasi sehingga dapat mengungkap pemanfaatan gua oleh manusia pendukungnya. Berawal dari informasi hasil penelitian tim Ekspedisi Intersains Lengguru-Kaimana tahun 2010, maka tim Balai Arkeologi Jayapura menelusuri dan melakukan penelitian pada tahun 2012. Penelitian terutama dengan melakukan ekskavasi pada areal gua Karas. Ekskavasi dilakukan pada sektor I (setelah melakukan layout permukaan lantai gua) dengan membuka 3 (tiga) kotak gali. 
Penamaan kotak gali pertama yaitu GKQ1 (I.6) dengan kedalaman galian $150 \mathrm{~cm}$, kotak kedua yaitu GKQ1 (F5) digali sedalam $130 \mathrm{~cm}$, dan yang ketiga yaitu GKQ1 (F6) galian mencapai kedalaman 120 $\mathrm{cm}$. Ekskavasi dari ketiga kotak menghasilkan temuan materi budaya yang cukup bervariasi yaitu fragmen keramik, fragmen tembikar, fragmen besi (ujung parang), tulang manusia, sisa-sisa makanan berupa cangkang moluska laut, cangkang moluska air tawar, tulang berbagai jenis fauna, biji tumbuhan, dan sisa pembakaran berupa arang.

Hasil kegiatan ekskavasi menunjukkan pemanfaatan ruang Gua Karas secara intensif ditandai dengan temuan arkeologis (dalam hal ini jejak-jejak budaya) baik artefak maupun sisa makanan (ekofak) yang bervariasi dan berjumlah banyak dalam lapisan budaya yang tebal. Fauna merupakan salah satu sumber alam yang biasa dieksploitasi untuk keperluan subsistensi manusia oleh karena itu jenis temuan ini, baik yang berupa artefak maupun ekofak, dapat dipakai sebagai alat untuk merekonstruksi aktivitas manusia. Dengan menggunakan data berupa tulang binatang, akan dapat diketahui jenis-jenis binatang yang telah dimanfaatkan untuk bahan makanan manusia (Subroto, 1986).

Pemanfaatan gua sebagai tempat tinggal membuktikan tidak semua gua dimanfaatkan secara intensif, bisa jadi hanya dimanfaatkan secara insidental. Pertimbangan manusia prasejarah dalam menempati suatu gua, selain didasarkan pada sumberdaya alam sekitarnya, juga didasarkan pada kenyamanan dan keamanan suatu gua dari gangguan alam (Suroto, et. al. 2012).

Berdasarkan kesimpulan dari penelitian ini, temuan yang ada dapat diketahui fungsi dari Gua Karas merupakan situs hunian yang menyatu dengan penguburan, hal ini dapat dilihat dari adanya temuan sisa-sisa aktifitas manusia masa lampau dan temuan tulang dan gigi manusia. Penguburan yang dilakukan gua Karas adalah penguburan langsung. Sisa-sisa materi budaya tersebut mengindikasikan bahwa situs Gua Karas pernah dimanfaatkan oleh manusia dalam jangka waktu yang cukup lama(Suroto, et. al. 2012).

Adanya interaksi antara manusia dengan lingkungan menyebabkan adanya dua macam lingkungan, yaitu lingkungan eksternal dan internal. Lingkungan eksternal merupakan kondisi dan segala sesuatu yang ada di sekitar manusia, seperti kelembaban, suhu, iklim dan kesuburan tanah. Sedangkan lingkungan internal merupakan readaptasi dan terdapat dalam diri manusia, yang ditimbulkan oleh aksi yang berasal dari lingkungan luar manusia (Riyanto, 1995).

Menurut Sally R. Binford dalam tulisan Mindra, menegaskan bahwa perbedaan variabel alat atau artefak yang terdapat pada suatu situs bila dapat dibandingkan dengan situs lain akan dapat menunjukkan beberapa perbedaan jenis pekerjaan atau aktivitas manusia pada masa lalu, juga adanya perbedaan fungsi untuk alat maupun situsnya sendiri (Mindra, 1989).

Informasi yang dikemukakan dari hasil penelitian tersebut, memberikan rekomendasi untuk ditindaklanjuti berkaitan dengan bentuk pemanfaatan ruang di gua Karas. Data ekskavasi dan adanya penempatan gambar pada gua Karas kiranya dapat mengungkap berkaitan dengan bentuk pemanfaatan gua Karas. Sehingga dapat mendukung interpretasi yang luas mengenai tinggalan arkeologis di gua Karas. Aspek inilah yang selanjutnya dilakukan dalam penelitian ini oleh tim Balai Arkeologi Jayapura. Selanjutnya dalam penelitian ini dengan perolehan data, tentunya melakukan survei dan ekskavasi pada gua Karas. Sehingga dapat menyingkap adanya 
pemanfaatan di gua Karas oleh manusia pendukungnya dalam proses rekonstruksi sejarah budaya.

\section{METODE PENELITIAN}

Waktu dan Tempat, penelitian ini telah dilaksanakan pada tanggal 18 - 23 Desember 2013. Lokasi gua Karas secara administratif terletak di Kampung Urisa, Distrik Arguni Bawah, Kabupaten Kaimana dengan titik astronomis berada pada posisi $03^{\circ} 19^{\prime}$ 27,2" lintang selatan dan $133^{\circ} 44^{\prime}$ '51,2" bujur timur dengan ketinggian $48 \mathrm{mdpl}^{9}$ Gua Karas berada di dalam gugusan karts dengan menyusuri sungai Karas yang melewati kampung Urisa kearah selatan.

Cara Pengumpulan Data dengan melalui: Observasi dengan melakukan pengamatan dan percatatan dengan sistematik yang diamati oleh penulis sesuai dengan tujuan penelitian. Ekskavasi dengan cara utama dalam memperoleh data sisa kehidupan masa lampau yang terdapat dalam tanah yang dipadukan dengan analisis pada objek kajian. Ekskavasi dilakukan dengan pendalaman tanah tiap spit $10-20 \mathrm{~cm}$ dengan bentuk kotak gali ukuran $1 \times 1$ meter. Setiap temuan dilakukan pencatatan/perekaman kedalam format pengumpulan data. Studi kepustakaan dilakukan dengan cara menelusuri literatur berupa artikel dan laporan penelitian yang telah dilakukan di situs gua Karas.
Metode Analisis Data, dalam penelitian ini dilakukan dengan cara mengklasifikasi dan identifikasi temuan permukaan dan hasil ekskavasi kemudian interpretasi. Secara umum analisis data dilakukan dengan cara deskriptif kualitatif.

\section{HASIL DAN PEMBAHASAN Temuan gambar gua Karas}

Struktur gua Karas berupa ruang kekar tiang yang memiliki ornamen stalaktit dan stalakmit serta terdapat pilar. Tipe gua Karas memanjang dengan intensitas cahaya baik. Kondisi lantai gua rata dengan permukaan tanahnya kering, terdapat sedimen moluska pada bagian bawah pilar di depan mulut gua. Pada gua Karas terdapat lukisan yang ditorehkan pada dinding dan langit-langit gua. Lukisan ini berwarna hitam dengan ini penempatan berada pada ruang terang dan gelap di gua Karas. Kondisi gambar sudah mengalami kerusakan, terlihat pada beberapa gambar telah aus atau tertutupi oleh lumut yang tumbuh dari karts. Adapun jumlah gambar yang diketahui sebanyak 22 buah.

Terdapat pula gambar yang sulit dikenali karena mengalami kerusakan atau aus. Gambar yang berhasil diidentifikasi berupa berupa gambar manusia, ikan, geometris, lingkaran, limas, grid. Untuk lebih jelasnya diuraikan dalam tabel 1 berikut ini:

Tabel 1. Temuan gambar di Gua Karas

\begin{tabular}{|c|c|c|c|}
\hline No. & Bentuk Gambar & Jumlah & Keterangan \\
\hline 1. & Manusia & 3 & $\begin{array}{l}2 \text { gambar berada pada langit-langit gua dekat pilar dan } 1 \text { gambar pada bagian } \\
\text { gelap/dalam langit-langit gua. * }\end{array}$ \\
\hline 2. & Ikan & 1 & Berada pada dinding luar gua, tepatnya bagian atas pilar kedua. ${ }^{*}$ \\
\hline 3. & Geometris & 2 & $\begin{array}{l}\text { Berada pada dinding luar gua, tepatnya bagian atas pilar kedua dan dinding barat } \\
\text { gua. * }\end{array}$ \\
\hline 4. & Lingkaran & 6 & Gambar berada pada langit-langit gua dekat pilar. * \\
\hline 5. & Limas & 1 & Berada pada dinding luar gua, tepatnya bagian atas pilar kedua. ${ }^{*}$ \\
\hline 6. & Grid & 4 & $\begin{array}{l}2 \text { gambar berada pada dinding luar gua, tepatnya bagian atas pilar kedua dan } 1 \\
\text { gambar berada pada tebing luar bagian atas pilar } 1 \text { serta } 1 \text { gambar berada pada } \\
\text { langit-langit bagian gelap pilar ketiga. * }\end{array}$ \\
\hline 7. & Unidentifikasi & 5 & $\begin{array}{l}3 \text { gambar berada pada dinding luar gua, tepatnya bagian atas pilar kedua dan } 2 \\
\text { gambar berada pada bagian gelap langit-langit gua dekat pilar ketiga. * }\end{array}$ \\
\hline
\end{tabular}

Sumber: Balai Arkeologi Jayapura, 2013 
Penempatan gambar ada yang berada pada dinding depan gua, dinding bagian barat gua, langitlangit gua dan pada pilar. Selain itu, ada yang membentuk panel/bingkai memuat beberapa gambar, ada yang berdekatan 2 gambar, ada yang hanya 1 gambar saja. $\quad \mathrm{P}$ e n e $\mathrm{m}$ p a t a $\mathrm{n}$ lukisan figuratif seperti bentuk manusia 3 buah dengan posisi berdiri dan jongkok berada pada langit-langit gua antara dinding timur gua dengan pilar pertama 2 buah lukisan, 1 buah lukisan berada pada bagian dalam/ gelap. Bentuk ikan 1 buah berada pada dinding luar gua yang merupakan bagian dari sebuah panel dalam penempatan lukisan, tepatnya pada bagian atas pilar kedua.

Sedangkan lukisan non figuratif seperti geometris 2 buah, masingmasing keletakannya berada pada dinding luar gua bagian atas pilar kedua, tepatnya berada pada panel gambar ikan dan 1 gambar berada pada dinding barat gua Karas. Bentuk lingkaran 6 buah berada langit-langit gua dekat pilar kedua dan bentuk grid 4 buah berada pada dinding luar gua, 2 buah pada bagian atas pilar kedua dan 1 buah gambar berada pada tebing luar bagian atas pilar pertama dan 1 gambar berada pada langit-langit bagian gelap atau dalam pilar ketiga.

Bentuk limas dengan motif anyaman berada pada bagian luar tebing di atas pilar kedua. Dan bentuk yang tidak teridentifikasi 5 buah gambar berada satu panel dengan ikan (foto 1).

Hasil Perolehan Temuan

\section{Ekskavasi}

Kegiatan ekskavasi di Gua Karas dilakukan dengan membuka dua buah kotak gali. Penempatannya berada pada bagian luar gua. Untuk kotak gali pertama penamaan kotaknya adalah GKQ1 (D6) dan untuk kotak gali kedua penamaannya GKQ2 (C6). Pada dasarnya penempatan kotak gali ini memperhatikan informasi temuan yang telah diperoleh dari penelitian sebelumnya yakni menemukan fragmen tulang manusia dan fragmen tembikar dalam tiap kotak gali. Tiap kotak tersebut berada pada bagian depan bongkahan batu gamping.

Penempatan kotak gali pertama GKQ1 (D6) berada pada grid sektor

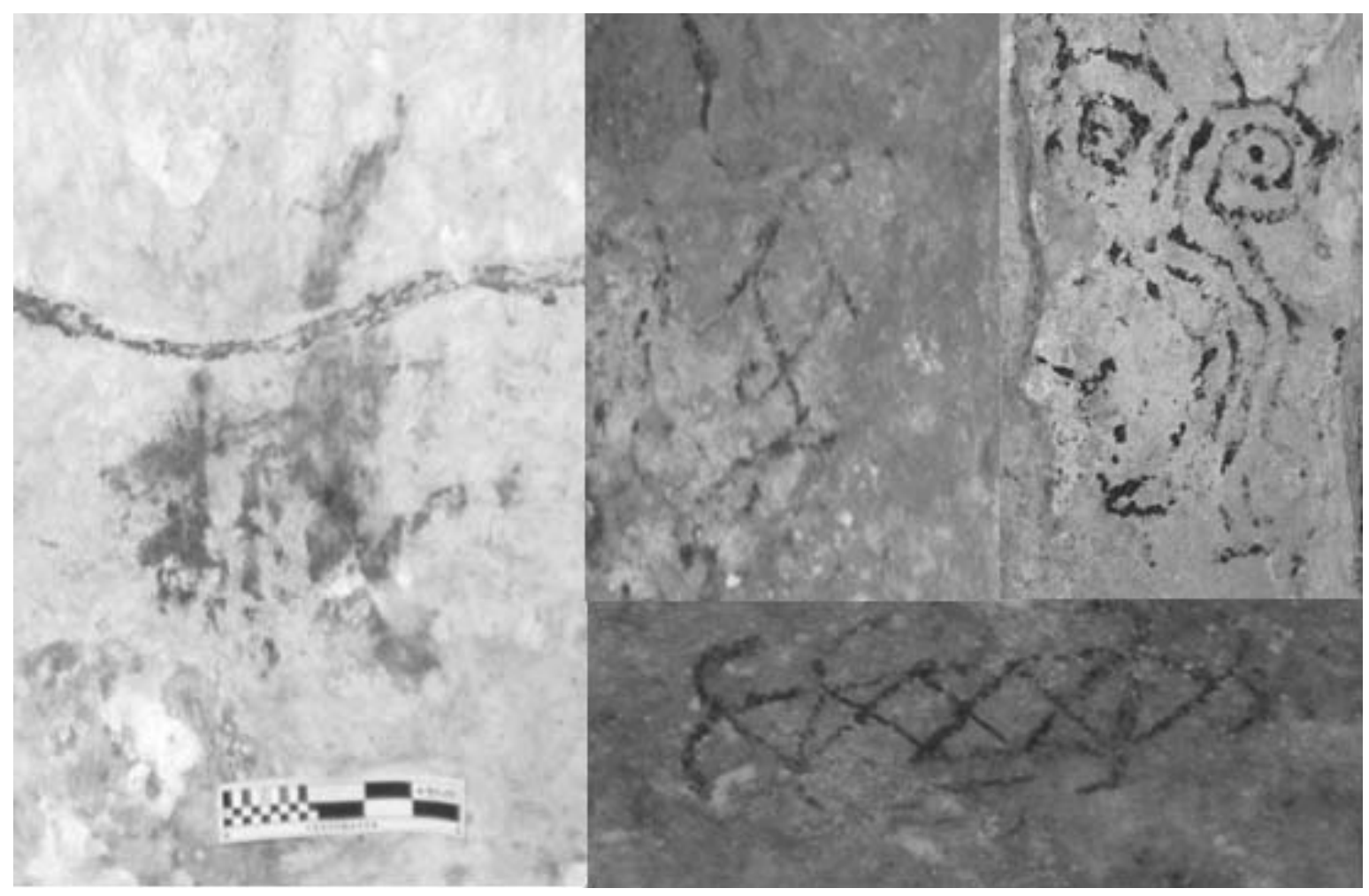


1 atau pada sisi timur dari kotak F6, sedangkan kotak kedua GKQ2 (C6) berada pada sebelah timur dari kotak GKQ1 (D6) atau tepatnya berada pada bagian depan pilar pertama. Penempatan kotak GKQ1 (D6) berada pada jarak 1 meter sisi timur kotak GKQ1 (F6). Penempatan ini dimaksudkan untuk melihat keterkaitan temuan yang diperoleh pada kotak GKQ1 (F6). Sedangkan Penempatan kotak gali GKQ2 (C6) berada pada sisi timur kotak GKQ1 (D6) dengan jarak 7 meter dan berada pada bagian depan pilar 1. Kondisi permukaan tanah lebih rendah dari kotak sebelumnya.

Berdasarkan perolehan temuan hasil ekskavasi pada kotak GKQ1 (D6) yang mencapai spit 9 dengan kedalaman $200 \mathrm{~cm}$ dari penempatan tali rata. Temuan tiap spit yang diperoleh kotak GKQ1 (D6) memperlihatkan 4 jenis temuan setelah diklasifikasikan. Temuan tersebut terdiri dari moluska (pelecypoda dan gastropoda), fragmen tulang, fragmen tembikar, dan arang. Sedangkan pada kotak GKQ2 (C6) memperlihatkan pula 4 (empat) jenis yaitu moluska (pelecypoda dan gastropoda), Arthopoda (brachyuran = kepiting), fragmen tulang, dan fragmen tembikar yang diperoleh sampai pada spit 4 dengan kedalaman $90 \mathrm{~cm}$ dari tali rata.

Pada kotak GKQ1 (D6) temuan moluska dari genus pelecypoda sejumlah 438 buah dari habitat laut, genus gastropoda sejumlah 2268 buah terdiri dari 33 buah dari habitat laut dan 2235 buah dari habitat sungai. Temuan fragmen tembikar polos bagian badan sejumlah 7 buah dan fragmen tembikar hias bagian badan sejumlah 1 buah. Untuk temuan fragmen tulang sejumlah 99 buah terdiri dari fragmen tulang ikan 10 buah, fragmen tulang mamalia 52 buah, fragmen tulang manusia (homo) 37 buah. Perolehan untuk sampel arang seberat 731 gram.

$$
\text { Untuk kotak GKQ2 }
$$

perolehan temuannya dari moluska genus pelecypoda sejumlah 176 buah dari habitat laut, genus gastropoda sejumlah 197 buah terdiri dari 24 buah dari habitat laut dan 173 buah dari habitat sungai, genus arthopoda (brachyuran $=$ kepiting sungai) sejumlah 9 buah. Temuan fragmen tembikar polos bagian badan sejumlah 3 buah dan fragmen tembikar hias bagian badan 1 buah. Fragmen tulang sejumlah 40 buah terdiri dari fragmen ikan 1 buah, dan fragmen mamalia 39 buah.

\section{Pemanfaatan Ruang Gua Karas}

Melihat lingkungan gua Karas yang berada pada sisi tebing atau sisi lereng memberikan ruang yang baik untuk beraktifitas sesuai dengan pemenuhan kelangsungan hidup. Keberadaan gua Karas yang berada pada bagian pedalaman gugusan karts dengan adanya sungai memungkinkan penghunian gua Karas mencerminkan lokasi dalam memenuhi kebutuhan hidup sepenuhnya tergantung pada lingkungan alam. Hal ini dapat diketahui dari perolehan temuan dari hasil penelitian dengan adanya temuan moluska, fragmen tulang binatang dan ikan.

Keberadaan temuan yang mencerminkan hasil eksploitasi manusia pendukung di gua Karas, memperlihatkan adanya usaha penghunian dengan memanfaatkan gua sebagai tempat kelangsungan hidup. Hal ini, karena gua pada umumnya memiliki sifat yang khas dalam pengaturan suhu udara didalamnya, jika udara di luar panas, keadaan ruangnya terasa sejuk. Namun, bila suhu di luar dingin ruang didalam akan sejuk. Selain itu, gua juga dimanfaatkan untuk berlindung dari ancaman binatang buas dan gejala alam yang ekstrim sehingga dengan sifat yang khas menjadikan gua pilihan utama pada masa lalu sebagai tempat 
berlindung bagi sebagian makhluk hidup.

Berdasarkan analisis stratigrafi pada umumnya temuan moluska, fragmen tulang mamalia, fragmen gerabah pada kotak GKQ1 (D6) dan kotak GKQ2 (C6) diperoleh pada layer pertama, berada pada tanah lempung dengan warna abu-abu kehitaman. Temuan ini mengindikasikan bahwa sisa aktifitas penghunian berada pada level layer abu-abu kehitaman sampai layer kehitaman. Mulai dari permukaan tanah sampai kedalaman $70 \mathrm{~cm}$.

Adanya sisa aktifitas penghunian seperti sisa makanan berupa moluska baik pelecypoda maupun gastropoda, fragmen tulang mamalia yang diperoleh dari ekskavasi gua Karas di 2 (dua) kotak. Moluska genus gastropoda dan genus pelecypoda yang berasal dari habitat laut dan habitat sungai/payau. Fragmen tulang mamalia berupa tulang penyu, tulang reptilia, tulang cervus (rusa) dan tulang ikan. Memberikan petunjuk suatu bukti akan keberadaan serta usaha dalam mempertahankan kelangsungan hidup. Ini berarti bahwa dengan adanya sisa aktivitas tersebut yang tersedia di lingkungan sekitar secara langsung mereka manfaatkan. Dalam hal ini dapat diketahui bahwa pemilihan suatu tempat untuk bermukim atau menetap terlebih dahulu melihat kondisi lingkungan sekitar terutama tempat sumber air dan lingkungan sumber daya yang cukup menyediakan kebutuhannya.

Jenis kebutuhan manusia pendukung kehidupan gua Karas umumnya terdapat pada sekitar keletakan gua yakni berada pada garis batas antara pegunungan karst dengan bibir sungai pada masa lalu, dengan demikian jenis makanan yang berupa ikan dan kerang-kerangan akan selalu tersedia di sekitar tempat tinggal mereka. Selain itu, dengan lingkungan dataran yang terdapat di sekitar gua, merupakan tempat hidupnya jenis- jenis hewan buruan dan umbi-umbian. Penggunaan gerabah pun terlihat dengan adanya fragmen gerabah yang diperoleh sebagai wadah dalam aktifitas memasak. Hal ini mencerminkan perilaku penghuni gua dengan memanfaatkan wadah dan memberikan asumsi bahwa adanya interaksi dengan masyarakat luar dalam menggunakan wadah. Berbicara tentang perkembangan teknologi dan variasi temuan yang dikembangkan oleh pendukung gua Karas. Data yang diperoleh hanya pada fragmen gerabah dengan warna merah kecoklatan. Fragmen gerabah baik polos maupun hias dengan motif garis-garis memperlihatkan wadah periuk. Kemungkinan sebagai wadah dalam menunjang aktifitas memasak karena terlihat bekas pembakaran dan berwarna kehitaman. Fragmen gerabah mengindikasikan adanya pola tingkah laku dari pendukung kebudayan gua Karas. Selain itu, kemungkinan gerabah diperoleh dari adanya interaksi ataupun kontak dengan masyarakat luar.

Pada sisi depan pilar pertama, tersingkap adanya deposit sampah dapur berupa cangkang moluska bercampur tulang mamalia. Temuan ekskavasi didukung pula dengan adanya sisa pembakaran berupa arang dan serangkaian bukti lain yang mendukung adanya aktivitas hidup. Selain itu, bukti penghunian yang cukup memungkinkan adanya temuan tinggalan arkeologis yang terdapat gua Karas terdapat ceruk dan di ruang Gua Karas pada sisi timur terdapat ceruk menyimpan fragmen tulang manusia. Bukti lainnya dengan adanya gambar berwarna hitam menyerupai gambar manusia, ikan, motif geometris, lingkaran, limas, dan grid pada pada dinding dan langit-langit gua Karas.

Mengacu pada terminologi rock art yang dikemukakan oleh L. Maynard (1977), asumsi para ahli bahwa lukisan 
atau pada Gua Karas dan sekitarnya, seperti temuan fragmen tulang manusia yang diperoleh pada hasil ekskavasi di kedalaman $150 \mathrm{~cm}$ pada kotak GKQ1 (D6), fragmen tulang ini berupa fibula dan humerus kemungkinan keberadaan fragmen ini merupakan bukti adanya penguburan dari penghunian gua. Selain itu pada sekitar gambar dengan warna hitam relatif lebih muda usianya dibandingkan lukisan berwarna merah. ${ }^{2}$ Untuk gambar lukisan pada Gua Karas memperlihatkan penorehan dengan teknik lukis.

Gambar pada gua Karas secara teknis terdiri dari lukisan figuratif dan non figuratif. Bentuk figuratif seperti gambar manusia dan ikan. Sementara bentuk non figuratif berupa gambar geometris, lingkaran, limas, dan grid. Pada umumnya gambar di gua Karas lebih banyak bentuk non figuratif.

Keberadaan

gambar mencerminkan adanya bentuk pengungkapan pada objek nyata dalam menjalani kehidupan penghuni gua Karas. Kemungkinan sebagai bentuk ekspresi seni ataupun dalam bentuk magis dalamupaya adaptasi lingkungan dalam memanfaatkan lingkungan sekitar. Selain itu, keberadaan lukisan memberikan petunjuk berkaitan dengan pemanfaatan ruang di gua Karas. Hal ini terlihat pada keletakan lukisan, misalnya gambar orang. Penempatan gambar orang pada sisi timur (antara dinding timur dan pilar pertama) yaitu pada langit-langit gua. Jika dihubungkan dengan temuan ekskavasi, pada penelitian terdahulu masing-masing kotak mengandung fragmen tulang manusia. Hal tersebut terdapat pada layer bawah pada kedalaman $150 \mathrm{~cm}$ pada kotak GKQ1 (D6) diperoleh fragmen manusia. Kemungkinan merupakan bentuk penguburan. Hal ini juga didukung pula dari data penelitian sebelumnya yang memperoleh fragmen tulang manusia pada kotak GKQ1 (F6 dan F5).

Pada gambar 1 di bawah ini memperlihatkan keletakan kotak gali pada halaman gua dan posisi gambar pada dinding/tebing di gua karas.

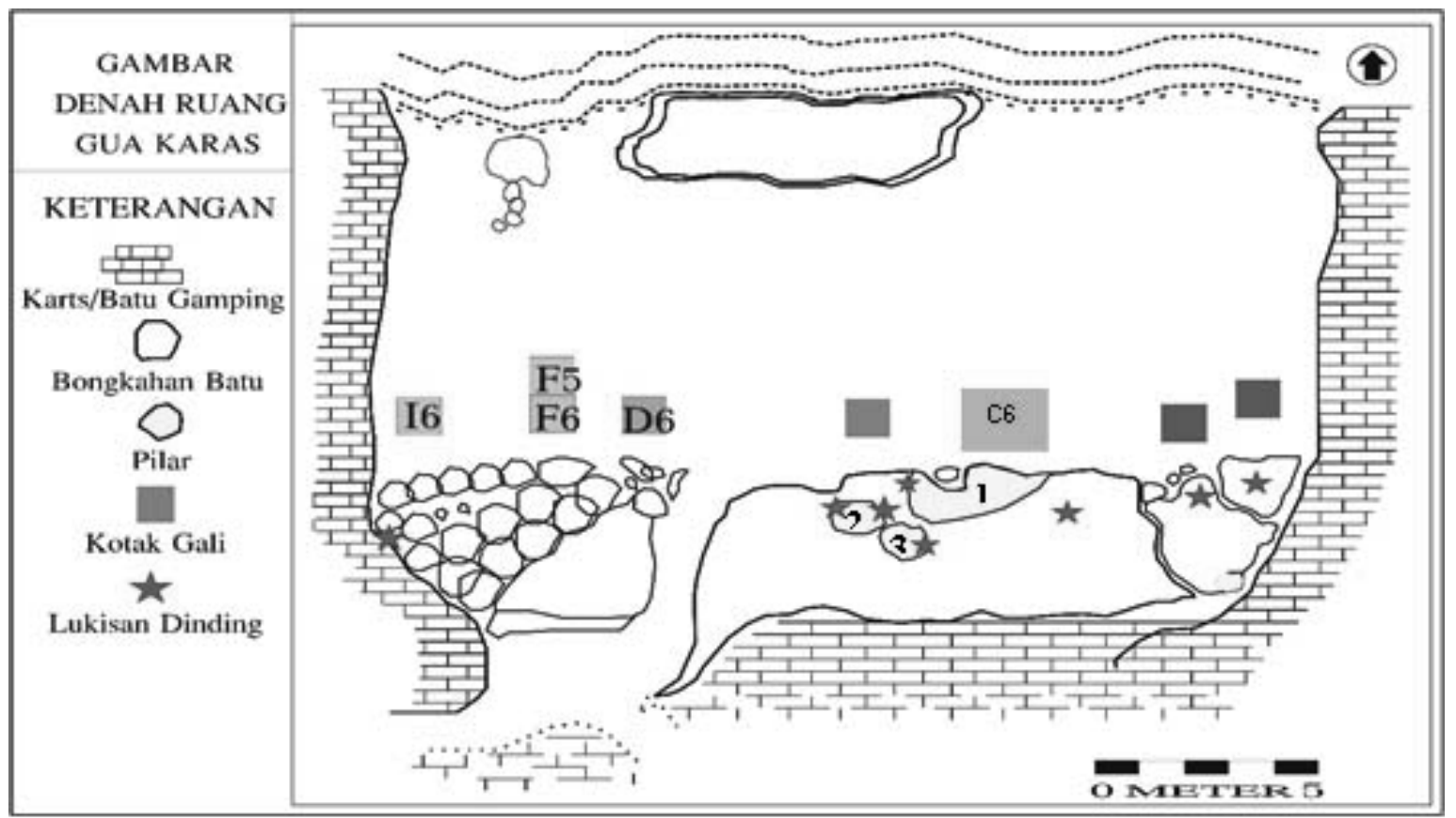

Peta 1. Denah Ruang Gua Karas 
Setiap penempatan gambar pada dinding maupun langit-langit gua terlihat adanya hubungan dengan ruang gua pada bagian depannya. Hasil ekskavasi memperlihatkan keterkaitan gambar lukisan dengan keberadaan fragmen tulang manusia. Ini berarti penempatan gambar kemungkinan berkaitan dengan bentuk penguburan yang dilakukan di gua Karas. Dengan kata lain, dalam penempatan lukisan memberikan semacam tanda berkaitan dengan tinggalan arkeologis pada sisi di bawah permukaan tanah.

\section{PENUTUP}

Penelitian dilakukan mengkonfirmasi pengungkapan sejarah budaya pada penghunian gua Karas. Secara umum berhubungan dengan cara-cara hidup. Hal ini terlihat dengan perolehan temuan yang memberikan pemahaman berkaitan dengan pemanfaatan gua sebagai ruang aktifitas di masa lalu dalam menjalani kehidupan juga mengeksploitasi lingkungan sekitar.
Data penghunian gua dengan memanfaatkan lingkungan sekitar. Mengeksploitasi sumberdaya alam untuk kelangsungan hidupnya hal ini terlihat pada temuan fragmen moluska dan fragmen tulang mamalia dari hasil ekskavasi. Pemanfaatan ruang gua sangat penelitian menunjukkan bahwa penghunian gua Karas telah berlangsung pada masa lalu. Pemanfaatan gua Karas dengan indikasi temuan artefak maupun ekofak dari hasil ekskavasi memperlihatkan bentuk terlihat dengan adanya penempatan gambar pada dinding dan langit-langit gua Karas. Kemungkinan sebagai wujud ekspresi seni ataupun dalam bentuk magis yang berkaitan dengan tanda penguburan.

Temuan tersebut menunjukkan pemanfaatan gua Karas sebagai gua hunian pada aspek horizontal sekaligus sebagai gua penguburan pada sisi vertikal. Namun hal ini, perlu dilakukan penelitian lebih mendalam untuk melihat keterkaitan ataupun pada kronologis pemanfaatan ruang gua Karas. 


\section{DAFTAR PUSTAKA}

http://lengguru.org diakses 20 Februari 2012.

Mindra, Faisaliskandar, 1989. Variabilitas Tipe Artefak sebagai Indikator Strategi Subsistensi : Kajian atas Strategi Perburuan Paleolitik Asia Tenggara. Makalah dalam Pertemuan IImiah Arkeologi V. Jakarta: Ikatan Ahli Arkeologi Indonesia.

Mulyadi, Yadi. 2004. Pengolahan Data Berbasis Komputer Lukisan Gua Prasejarah Maros-Pangkep. Fakultas Sastra. Makassar: Universitas Hasanuddin.

Nurani, Indah Asikin. 2002. Pola-pola Pemanfaatan Gua Kawasan Timur Jawa. Kumpulan Makalah Pertemuan IImiah Arkeologi Ke-IX Kediri, 23-28 Juli 2002. Jakarta: Ikatan Ahli Arkeologi Indonesia. HIm. 95-112.

Wiradnyana, Ketut. 2011. Prasejarah Sumatera Bagian Utara: Kontribusinya pada Kebudayaan kini. Jakarta: Obor.

Riyanto, Sugeng. 1995. Geografi (Kesejarahan) dan Arsitektur (Landsekap) Sebagai Ilmu Bantu Arkeologi (Sebuah Uraian Singkat). Berkala Arkeologi Tahun XV Edisi Khusus. Balai Arkeologi Yogyakarta.

Subroto, Ph. 1986. Manfaat Temuan Tulang Binatang untuk Penelitian Arkeologi. Makalah dalam Pertemuan Ilmiah Arkeologi IV. Jakarta: Pusat Penelitian Arkeologi Nasional. HIm. 491-502.

Suroto, Hari, dkk, 2012. Ekskavasi Gua Karas Kabupaten Kaimana. Laporan Penelitian. Balai Arkeologi Jayapura.

Mas'ud, Zubair. 2013. Ekskavasi di Gua Karas Kawasan Teluk Arguni Kabupaten Kaimana. Laporan Penelitian. Balai Arkeologi Jayapura 